\title{
PENGARUH PENAMBAHAN FILLER GRANIT DAN KERAMIK PADA CAMPURAN LASTON AC-WC TERHADAP KARAKTERISTIK UJI MARSHALL
}

\author{
Fasdarsyah, Mukhlis, Sulaiman \\ Dosen Jurusan Teknik Sipil, Universitas Malikussaleh
}

\begin{abstract}
Abstrak
Lapis Beton Aspal adalah lapisan penutup konstruksi perkerasan jalan yang mempunyai nilai structural. Salah satu jenis lapis beton aspal tersebut adalah Asphall Concrete - Wearing Course (AC-WC) sebagai lapisan yang paling atas dalam perkerasan lentur. Material utama penyusun adalah agregat dan aspal, termasuk jenis filler dalam penggunaannya. Dalam penelitian ini jenis filler yang di gunakan adalah abu batu,abu granit dan abu keramik sebagai pembandingnya. Sebelum dilakukan pengujian Marshall pada campuran, dilakukan pengujian terhadap material yang digunakannya. Hasil pengujian berat jenis pada filler keramik adalah $2,573 \mathrm{gr} / \mathrm{cm}^{3}$ dan $2,585 \mathrm{gr} / \mathrm{cm}^{3}$ untuk filler granit, sedangkan material lolos ayakan no. 200 (75 micron) pada filler abu keramik dan abu granit diambil 5\%,10\%,15\%,20\% dan $25 \%$ sedangkan sisanya merupakan abu batu dari 72 gram target gradasi. Kadar aspal rencana yang digunakan baik pada campuran dengan filler abu keramik maupun abu granit adalah $\mathrm{pb}=5,5 \%$ dengan rentang kadar aspal rencana $4 \%, 4,5 \%, 5 \%, 5,5 \%$ dan $6 \%$. Setelah dilakukan uji marshall dengan kadar aspal rencana, seluruh sifat marshall pada uji standar 2x75 tumbukan telah memenuhi spesifikasi yang disyaratkan. Hasil yang diperoleh adalah kepadatan dan stabilitas marshall dengan abu granit memiliki nilai lebih tinggi dari pada campuran dengan abu keramik. Pada seluruh rentang kadar aspal, nilai flow campuran dengan filler abu keramik lebih tinggi dari pada campuran dengan filler abu granit,Nilai tertinggi pada abu keramik sebesar 6,63 mm, sedangkan abu granit sebesar 4,87 mm. Marshall Quottient untuk kedua jenis filler, nilai terendah terjadi pada kadar aspal tertinggi $(25 \%)$ yaitu sebesar $396 \mathrm{~kg} / \mathrm{mm}$ untuk filler abu keramik dan pada kadar aspal (5\%) yaitu sebesar $452 \mathrm{~kg} / \mathrm{mm}$ untuk filler abu granit. Filler abu granit memiliki nilai VFA lebih tinggi daripada abu keramik, namun nilai VMA lebih rendah. Sedangkan nilai Rongga udara dalam campuran (VIM), filler abu keramik lebih tinggi dari pada abu granit.
\end{abstract}

Kata Kunci: Laston AC-WC, Filler granit dan Filler keramik Uji Marshall

\section{Pendahuluan}

Beton aspal adalah jenis perkerasan jalan yang terdiri dari campuran agregat dan aspal, dengan atau tanpa bahan tambahan. Salah satu produk campuran aspal yang kini banyak digunakan adalah $A C$-WC (Asphalt ConcreteWearing Course)/Lapis Aus Aspal Beton. Seiring dengan semakin banyaknya bahan campuran perkerasan yang telah digunakan di lapangan dan bertambahnya kenderaan sehingga menyebabkan cepat rusak dan retaknya pada permukaan perkerasan, maka perlu mencoba dan merencanakan terhadap material yang murah dan efesien. Sehingga penulis melakukan penelitian dengan menggunakan Campuran filler Keramik dan filler Granit pada campuran laston AC-WC terhadap karakteristik Uji Marshall sebagai alternatif pemecahan masalah tersebut dan juga mengetahui berapa besar pengaruh terhadap Stabilitas yang tinggi dan tetap mempertahankan terhadap kelenturan, Durabilitas (keawetan), Fleksibilitas, 
mempunyai ketahanan terhadap kelelahan,kedap air dan mudah untuk dilaksanakan dengan menggunakan varian campuran filler 5\%,10\%,15\%,20\% dan $25 \%$ baik untuk filler keramik maupun filler granit. Dengan dilakukan penelitian ini maka diharapkan apabila kedua jenis filler yang digunakan memenuhi persyaratan terhadap sifat-sifat parameter marshall sehingga kedua jenis filler ini bisa dikembangkan sebagai pengganti abu batu sebagai bahan pengisi yang digunakan saat ini dengan mengurangi persentase aspal kedalam produktivitas campuran aspal beton, berdasarkan kinerja pencampurannya yaitu gradasi dan sifat aspal. Adapun tujuan penelitian yaitu membandingkan penggunaan filler granit dan filler keramik pada karakteristik uji Marshall dari pengaruh pada campuran laston AC-WC dan untuk mengetahui dan menganalisis pengaruh pemanfaatan antara filler granit dan filler keramik terhadap nilai uji Marshall pada campuran laston AC-WC.

\section{Tinjauan Kepustakaan}

\subsection{Laston AC-WC (Asphalt Concrete-Wearing Course)}

Material utama penyusun suatu campuran aspal sebenarnya hanya dua macam, yaitu agregat dan aspal. Namun dalam pemakaiannya aspal dan agregat bisa menjadi bermacam - macam, tergantung kepada metode dan kepentingan yang dituju pada penyusunan suatu perkerasan. Salah satu produk campuran aspal yang kini banyak digunakan oleh Departemen Permukiman dan Prasarana Wilayah adalah $A C$-WC (Asphalt Concrete - Wearing Course)/Lapis Aus Aspal Beton. $A C$ - $W C$ adalah salah satu dari tiga macam campuran lapis aspal beton yaitu $A-W C, A C-B C$ dan AC-Base. Ketiga jenis Laston tersebut merupakan konsep spesifikasi campuran beraspal yang telah disempurnakan oleh Bina Marga bersama-sama dengan Pusat Litbang Jalan. Dalam perencanaan spesifikasi baru tersebut menggunakan pendekatan kepadatan mutlak. Penggunaan $A C$ - $W C$ yaitu untuk lapis permukaan (paling atas) dalam perkerasan dan mempunyai tekstur yang paling halus dibandingkan dengan jenis laston lainnya. Pada campuran laston yang bergradasi menerus tersebut mempunyai sedikit rongga dalam struktur agregatnya dibandingkan dengan campuran bergradasi senjang. Hal tersebut menyebabkan campuran AC-WC lebih peka terhadap variasi dalam proporsi campuran.

\subsection{Aspal}

Sukirman, S (1999), menyatakan Aspal merupakan material berwarna hitam atau coklat tua, pada temperatur ruang berbentuk padat sampai agak padat. Jika dipanaskan sampai suatu temperatur tertentu aspal dapat menjadi lunak/cair sehingga dapat membungkus partikel agregat pada waktu pembuatan campuran aspal beton. Fungsi aspal dalam campuran agregat aspal adalah sebagai bahan pengikat yang bersifat visco-elastis dengan tingkat viscositas yang tinggi selama masa pelayanan dan berfungsi sebagai pelumas pada saat penghamparan di lapangan sehingga mudah untuk dipadatkan. Untuk merancang komposisi campuran benda uji, pertama-tama dilakukan dengan menentukan nilai kadar aspal tengah dengan menggunakan rumus sebagai berikut:

$$
P_{b}=0,035(\% C A)+0,045(\% F A)+0,18(\% \text { Filler })+F .
$$

Pengaruh Penambahan Filler Granit dan Keramik Pada Campuran Laston AC-WC Terhadap Karakteristik Uji Marshall - Fasdarsyah, Mukhlis, Sulaiman 
Keterangan:

$\mathrm{P}_{\mathrm{b}} \quad$ : Kadar aspal tengah, $\%$

$\mathrm{CA}$ : Coarse agregate (agregat kasar)

FA : Fine agregate (agregat halus)

F : Konstanta $(0,5 \%-1,0 \%)$ untuk laston

Setelah mendapatkan nilai $\mathrm{Pb}$, kemudian dibuat lima variasi kadar aspal untuk menentukan kadar aspal optimum yaitu pada kadar aspal $\mathrm{Pb}-1, \mathrm{~Pb}-0,5, \mathrm{~Pb}$, $\mathrm{Pb}+0,5, \mathrm{~Pb}+1$.

Nilai kadar aspal optimum (KAO) antara lain dapat dicari dengan cara grafis dan menggunakan nilai CAD (Compacted Agregate Density). Cara grafis dilakukan dengan menarik nilai tengah pada rentang kadar aspal yang memiliki karakteristik Marshall memenuhi persyaratan spesifikasi. Melalui penggunaan nilai $\mathrm{CAD}$, kadar aspal optimum didapat dengan cara mengambil nilai rata-rata kadar aspal dari 2 (dua) karakteristik Marshall dan 1 (satu) kadar aspal pada nilai CAD maksimum. Dua nilai kadar aspal pada karakteristik Marshall adalah kadar aspal pada saat nilai maksimum density dan kadar aspal pada saat nilai maksimum stability. Nilai Compacted Agregate Density diperoleh dengan menggunakan rumus berikut:

$$
C A D=\frac{W a(100-D b\rangle}{100 x V}
$$

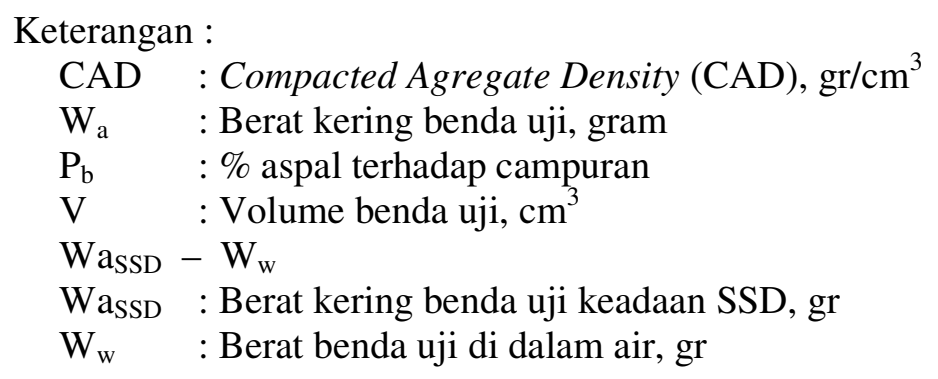

Dua sifat yang diperoleh dengan menggunakan metode Marshall adalah stabilitas dan kelelahan. Melalui metode Marshall juga akan diperoleh analisa rongga yang dilakukan dengan pengukuran terhadap benda uji dan menghasilkan parameter-parameter berupa kepadatan (density), VMA (Voids In the Mineral Agregate), VIM (Voids in the Mix) dan VFA (Voids Filled with Asphalt). Marshall Quotient (MQ) merupakan hasil bagi stabilitas dengan kelelahan. Nilai MQ dipakai sebagai pendekatan tingkat kekakuan dan fleksibilitas campuran.

Melalui pengujian dengan alat Marshall dapat diketahui beberapa karakteristik campuran aspal sebagai berikut:

1. Penentuan berat volume benda uji

2. Pengujian nilai stabilitas

3. Pengujian kelelahan

4. Perhitungan quotient Marshall

5. Perhitungan berbagai jenis volume pori dalam campuran (VIM, VMA, dan VFA)

6. Perhitungan tebal selimut atau film aspal 
Untuk mengetahui parameter-parameter Marshall campuran aspal berupa stabilitas, kelelehan plastis (Flow), berat isi (Density), rongga dalam butiran (VMA), rongga dalam campuran (VIM), rongga terisi aspal (VFA)dan Marshall Quotient (MQ).

1. Penentuan kerapatan (density)

$$
\text { Densily }=\frac{\text { Eerat kerng benda uju (gr] }}{\text { Vslume benda uji }\left(\mathrm{cm}^{3}\right)}
$$

2. Stabilitas (stability)

Nilai stabilitas $(\mathrm{kg})=$ Nilai pembacaan arlojl stabilitas $\mathrm{x}$

kalibrasi prowing ring $\mathrm{x}$ koreksi tebal benda uji

3. Pengujian kelelahan (flow)

Nilai flow = nilai pembacaan arloji flow pada pengujian Marshall dengan satuannya milimeter $(\mathrm{mm})$

4. Rongga di antara mineral agregat (VMA)

$$
V M A=100-\frac{G m b x F z}{G s b} \text {. }
$$

Keterangan :

VMA : Rongga udara pada mineral agregat, persentase dari volume total (\%)

$\mathrm{G}_{\mathrm{mb}} \quad$ : Berat jenis campuran setelah pemadatan ( $\left.\mathrm{gr} / \mathrm{cc}\right)$

$\mathrm{P}_{\mathrm{s}} \quad$ : Kadar agregat, persen terhadap berat total campuran (\%)

$\mathrm{G}_{\mathrm{sb}} \quad$ : Berat jenis bulk agregat, (gr/cc)

5. Rongga di dalam campuran (VIM)

$V I M=100-\frac{G m b \times C m b}{G m m}$

Keterangan :

VIM : Rongga udara pada campuran setelah pemadatan, prosentase dari volume total, (\%)

$\mathrm{G}_{\mathrm{mm}}$ : Berat jenis campuran maksimum teoritis setelah pemadatan (gr/cc)

$\mathrm{G}_{\mathrm{mb}}$ : Berat jenis campuran setelah pemadatan ( $\left.\mathrm{gr} / \mathrm{cc}\right)$

6. Rongga udara yang terisi aspal (VFA)

$V F A=100-\frac{G m b x \mathrm{cmb}}{G m m}$

Keterangan :

VFA : Rongga udara yang terisi aspal, prosentase dari VMA, (\%)

VMA : Rongga udara pada mineral agregat, $\%$ dari volume total

VIM : Rongga udara pada campuran setelah pemadatan, prosentase dari volume total, $(\%)$

7. Perhitungan Marshall Quotient $(M Q)$

$V F A=\frac{M S}{M F}$.

Keterangan :

MQ : Marshall Quotient, $(\mathrm{kg} / \mathrm{mm})$

MS : Marshall Stability (kg)

MF : Flow Marshall, (mm)

Pengaruh Penambahan Filler Granit dan Keramik Pada Campuran Laston AC-WC Terhadap Karakteristik Uji Marshall - Fasdarsyah, Mukhlis, Sulaiman 


\subsection{Metode Marshall}

Rancangan campuran berdasarkan metode Marshall ditemukan oleh Bruce Marshall, dan telah distandarisasi oleh ASTM ataupun AASHTO melalui beberapa modifikasi, yaitu ASTM D 1559-76, atau AASHTO T-245-90. Prinsip dasar metode Marshall adalah pemeriksaan stabilitas dan kelelehan (flow), serta analisis kepadatan dan pori dari campuran padat yang terbentuk. Alat Marshall merupakan alat tekan yang dilengkapi dengan proving ring (cincin penguji) berkapasitas 22,2 KN (5000 lbs) dan flow meter. Proving ring digunakan untuk mengukur nilai stabilitas, dan flow meter untuk mengukur kelelehan plastis atau flow. Benda uji Marshall berbentuk silinder berdiameter 4inchi $(10,2 \mathrm{~cm})$ dan tinggi 2,5 inchi $(6,35 \mathrm{~cm})$. Prosedur pengujian Marshall mengikuti SNI 06-24891991, atau AASHTO T 245-90, atau ASTM D 1559-76. Secara garis besar pengujian Marshall meliputi: persiapan benda uji, penentuan berat jenis bulk dari benda uji, pemeriksaan nilai stabilitas dan flow, dan perhitungan sifat volumetric benda uji.

\subsection{Keramik}

Bahan baku Keramik terdiri dari tiga bahan baku utama yang digunakan untuk membuat produk keramik klasik, atau "triaksial", adalah lempung, feldspar dan pasir. Lempung adalah aluminium silikat hidrat yang tidak terlalu murni yang terbentuk sebagai hasil pelapukan dari batuan beku yang mengandung feldspar sebagai salah satu mineral asli yang penting. Reaksinya dapat dilukiskan sebagai berikut :

$$
\mathrm{K}_{2} \mathrm{O} \mathrm{Al} \mathrm{O}_{3} \cdot 6 \mathrm{SiO}_{2}+\mathrm{CO}_{2}+2 \mathrm{H}_{2} \mathrm{O} \longrightarrow \mathrm{K}_{2} \mathrm{CO}_{3}+\mathrm{Al}_{2} \mathrm{O}_{3} \cdot 2 \mathrm{SiO}_{2} \cdot 2 \mathrm{H}_{2} \mathrm{O}+4 \mathrm{SiO}_{2}
$$

Ada sejumlah spesies mineral yang disebut mineral lempung (clay mineral) yang mengandung terutama campuran kaolinit $\left(\mathrm{Al}_{2} \mathrm{O}_{3} \cdot \mathrm{SiO}_{2} \cdot 2 \mathrm{H}_{2} \mathrm{O}\right)$, montmorilonit $\left[(\mathrm{Mg}, \mathrm{Ca}) \mathrm{O} . \mathrm{Al}_{2} \mathrm{O}_{3} .5 \mathrm{SiO}_{2} \cdot \mathrm{nH}_{2} \mathrm{O}\right]$, dan ilit $\left(\mathrm{K}_{2} \mathrm{O}, \mathrm{MgO}, \mathrm{Al}_{2} \mathrm{O}_{3}, \mathrm{SiO}_{2}, \mathrm{H}_{2} \mathrm{O}\right)$ masingmasing dalam berbagai kuantitas. Dari sudut pandang keramik, lempung berwujud plastik dan bisa dibentuk bila cukup halus dan basah, kaku bila kering, dan kaca (vitreous) bila dibakar pada suhu yang cukup tinggi. Prosedur pembuatannya mengandalkan kepada sifat-sifat tersebut diatas.

\subsection{Granit}

Ada variasi dalam persentase mineral yang terkandung dalam berbagai jenis granit memberikan berbagai warna. Ini adalah mengapa granit ditemukan dalam warna hitam tapi juga tersedia dalam jenis berbutir dengan adanya garis-garis warna lainnya. Batuan ini terbentuk dari hasil pembekuan magma berkomposisi asam yang membeku di dalam dapur magma, sehingga batu ini merupakan jenis batu beku dalam. Massa jenis sekitar 2,2 - 2,3 gram/cm3. Batuan ini terkadang ditemukan di dataran rendah yang dinaungi bukit-bukit. Biasanya batu ini terbentuk di area lempeng tektonik. Granit biasanya ditemukan dalam bentuk batuan besar, keras, dan kokoh. Itulah mengapa granit banyak digunakan dalam konstruksi bangunan. Kepadatan sebuah batuan granit biasanya berkisar antara $2,65-2,75 \mathrm{~g} / \mathrm{cm} 3$. Batu ini bisa dilelehkan, tetapi dibutuhkan suhu yang sangat tinggi, yakni sekitar 1.215 - 1.260 derajat celcius.

Pengaruh Penambahan Filler Granit dan Keramik Pada Campuran Laston AC-WC 


\section{Metode Penelitian}

Metode penelitian yang digunakan adalah metode uji laboratorium. Material yang akan digunakan dalam penelitian ini diperiksa terlebih dahulu di laboratorium untuk memperoleh karakteristik dari material tersebut. Data yang dihasilkan dilaboratorium, digunakan untuk perencanaan campuran, selanjutnya dibuat benda uji (briket) untuk dilakukan uji Marshall sehingga diketahui karakteristik fisik dari setiap campuran.

Spesifikasi bahan yang meliputi gradasi agregat campuran yang diinginkan dan dicampurkan dengan filler granit maupun keramik yang lolos saringan no 200 , kemudian rancangan proporsi agregat menentukan kadar aspal tengah untuk mendapatkan nilai tengahnya dengan cara menghitungnya terlebih dahulu. Setelah itu benda uji dibuat untuk memperoleh nilai KAO, kemudian uji marshal dan hitung parameter Marshall, setelah didapat nilai aspal optimum, maka dibuat benda uji masing-masing 15 buah benda uji dengan campuran aspal dan filler. kemudian uji standar stabilitas dan flow dengan alat marshall setelah didapat hasilnya hitung parameter marshall yaitu Density, VITM, VMA dan VFWA.

Untuk menentukan kadar aspal optimum dilakukan penyiapan benda uji untuk tes Marshall sesuai tahapan berikut ini:

a. Berdasarkan perkiraan kadar aspal optimum $\mathrm{Pb}$ dibuat benda uji dengan jenis aspal pertamina dengan dua variasi kadar aspal di atas $\mathrm{Pb}$ dan dua variasi kadar aspal di bawah $\mathrm{Pb}(-1,0 \% ;-0,5 \% ; \mathrm{Pb} ;+0,5 \% ;+1,0 \%)$ serta variasi komposisi Filler dengan dibuat masing-masing 2 (dua) benda uji. Untuk variasi komposisi kadar filler adalah 100\% keramik, 50\% keramik $+50 \%$ granit dan $100 \%$ granit. Kemudian dilakukan pengujian Marshall standar dengan 2x75 tumbukan dan pengujian durabilitas untuk menentukan VIM, VMA, VFA, kepadatan, stabilitas, kelelehan, hasil bagi Marshall dan indeks stabilitas sisa. Dari hubungan antara kadar aspal dengan parameter Marshall, dapat ditentukan kadar aspal optimum.

b. Setelah didapatkan kadar aspal optimum maka dilakukan pembuatan benda uji dengan variasi komposisi filler yaitu $100 \%$ keramik, 50\% keramik $+50 \%$ granit dan $100 \%$ granit pada durasi perendaman 30 menit. Kemudian dilakukan uji marshall dengan kondisi stadar (2x75 tumbukan) untuk menentukan VIM, VMA, VFA, kepadatan, stabilitas, kelelehan dan hasil bagi Marshall, serta pengujian durabilitas standar dan durabilitas modifikasi untuk menentukan nilai indeks durabilitas pertama $(r, R)$ dan nilai indeks durabilitas kedua $(a, S a)$. Seluruh kriteria hasil Marshall yang didapatkan mengacu pada standar Departemen Pekerjaan Umum Bina Marga (2010).

Tabel 1: Jumlah benda uji yang akan dibuat

\begin{tabular}{|c|c|c|c|c|c|c|}
\hline \multirow{2}{*}{ Benda uji } & \multicolumn{5}{|c|}{ Kadar aspal tengah $(\mathrm{Pb})$} & \multirow{2}{*}{ Jumlah } \\
\hline & 4 & 4,5 & 5 & 5,5 & 6 & \\
\hline $\mathrm{AC}$ & 3 & 3 & 3 & 3 & 3 & 15 \\
\hline \multicolumn{7}{|c|}{ Kadar aspal optimum (KAO) } \\
\hline \multirow{2}{*}{ Benda uji } & \multicolumn{5}{|c|}{ Aspal Keramik \% } & Jumlah \\
\hline & $5 \%$ & $10 \%$ & $15 \%$ & $20 \%$ & $25 \%$ & \multirow{2}{*}{15} \\
\hline Jumlah & 3 & 3 & 3 & 3 & 3 & \\
\hline & \multicolumn{5}{|c|}{ Aspal Granit \% } & \\
\hline Benda Uji & $5 \%$ & $10 \%$ & $15 \%$ & $20 \%$ & $25 \%$ & \multirow{2}{*}{15} \\
\hline Jumlah & 3 & 3 & 3 & 3 & 3 & \\
\hline \multicolumn{6}{|c|}{ Total keseluruhan benda uji } & 30 \\
\hline
\end{tabular}

Pengaruh Penambahan Filler Granit dan Keramik Pada Campuran Laston AC-WC Terhadap Karakteristik Uji Marshall - Fasdarsyah, Mukhlis, Sulaiman 


\section{Hasil dan Pembahasan}

\subsubsection{Pengaruh Filler Keramik dan Filler Granit terhadap density}

besaran Nilai density hasil pengujian diperlihatkan pada gambar di bawah ini:

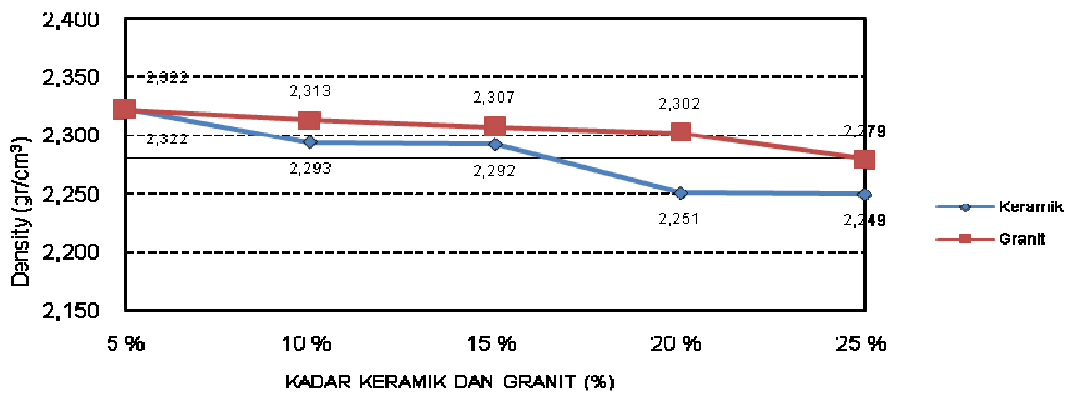

Gambar 1 Grafik hubungan variasi Filler terhadap nilai density.

Nilai density dari campuran aspal panas dengan variasi Filler Keramik dan Filler Granit memiliki variasi nilai tersendiri, yaitu pada kadar 5\% nilai density lebih rendah dari penggunaan $0 \%$, untuk keramik nilai $5 \%$ yaitu $2,322 \mathrm{gr} / \mathrm{cm}^{3}$ dan pada kadar $25 \%$ nilainya terjadi penurunan yaitu $2,249 \mathrm{gr} / \mathrm{cm}^{3}$ sedangkan granit nilai $5 \% 2,322 \mathrm{gr} / \mathrm{cm}^{3}$ sedangkan pada $25 \%$ nilainya $2,279 \mathrm{gr} / \mathrm{cm}^{3}$, dan terus menurun seiring dengan bertambahnya persentase kadar Filler Keramik dan Filler Granit dalam campuran akan tetapi kedua filler ini nilai yang tertinggi penurunan terjadi pada filler granit. Hal ini diakibatkan karena rongga yang ada belum sepenuhnya terisi oleh aspal, sehingga memungkinkan campuran untuk dapat lebih padat lagi.

\subsubsection{Pengaruh Filler Keramik dan Filler Granit terhadap VMA (void in the mineral aggregat )}

Nilai VMA yang diperoleh dari hasil penelitian diperlihatkan pada gambar 2 di bawah iniı,ou

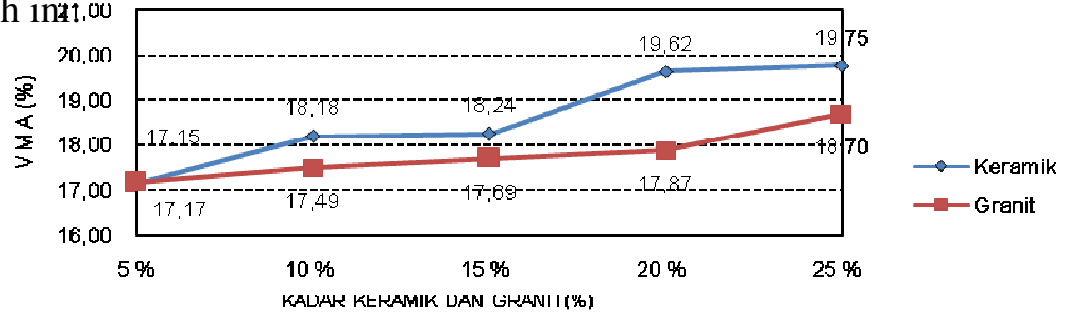

Gambar 2 Grafik hubungan variasi Filler terhadap nilai VMA

VMA akan meningkat jika selimut aspal lebih tebal, dari gambar diatas terlihat bahwa nilai VMA pada campuran aspal mengalami kenaikan pada kadar 5\% dan nilai VMA lebih besar dari $0 \%$ dan terus meningkat seiring dengan bertambahnya kadar Filler Keramik dan Filler Granit dalam campuran dan dari kedua filler ini nilai tertinggi terjadi pada campuran dengan filler keramik yaitu sebesar $19,75 \%$ pada kadar 25\% sedangkan Granit pada kadar $25 \%$ yaitu $18,70 \%$. Dapat disimpulkan bahwa nilai VMA akan mengalami penurunan seiring dengan berkurangnya kadar Filler tersebut dalam campuran AC-WC 


\subsubsection{Pengaruh Filler Keramik dan Filler Granit terhadap VITM (void in the mix)}

Nilai VITM yang diperoleh dari hasil penelitian ini dapat dilihat pada gambar 3 dibawah ini.

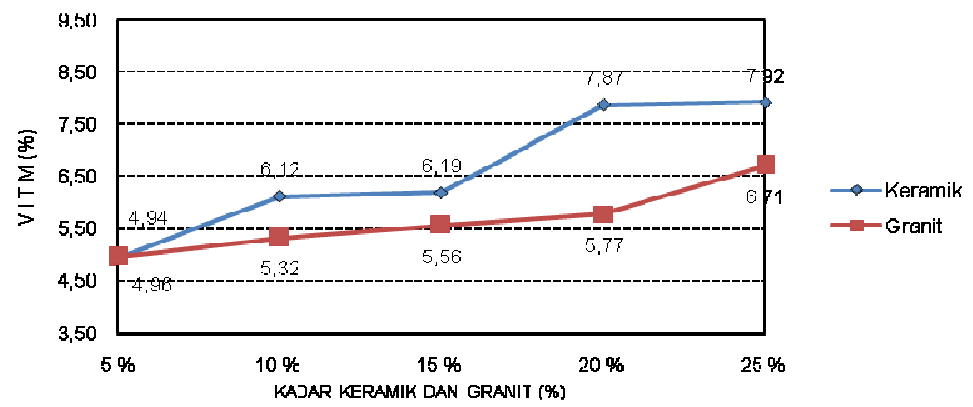

Gambar 3 Grafik hubungan variasi Filler terhadap nilai VITM

Dari gambar diatas terlihat bahwa nilai VITM pada campuran aspal mengalami peningkatan pada kadar 5\% baik untuk filler keramik maupun filler granit. Maka dapat diambil kesimpulan bahwa nilai VITM mengalami peningkatan seiring dengan bertambahnya kadar Filler tersebut akan tetapi pada keramik pada kadar filler keramik $10 \%, 15 \%, 20 \%$ dan $25 \%$ tidak memenuhi spesifikasi sedangkan pada filler granit $15 \%, 20 \%$ dan $25 \%$ tidak memenuhi spesifikasi, dimana spesifikasi yang di bolehkan yaitu minimal 3,5\% dan maksimal 5,5\%.

\subsubsection{Pengaruh Filler Keramik dan Filler Granit terhadap VFWA (voids filled with asphalt)}

Hubungan antara kadar filler Keramik dan filler granit dengan nilai VFWA dapat di lihat pada gambar 4 berikut :

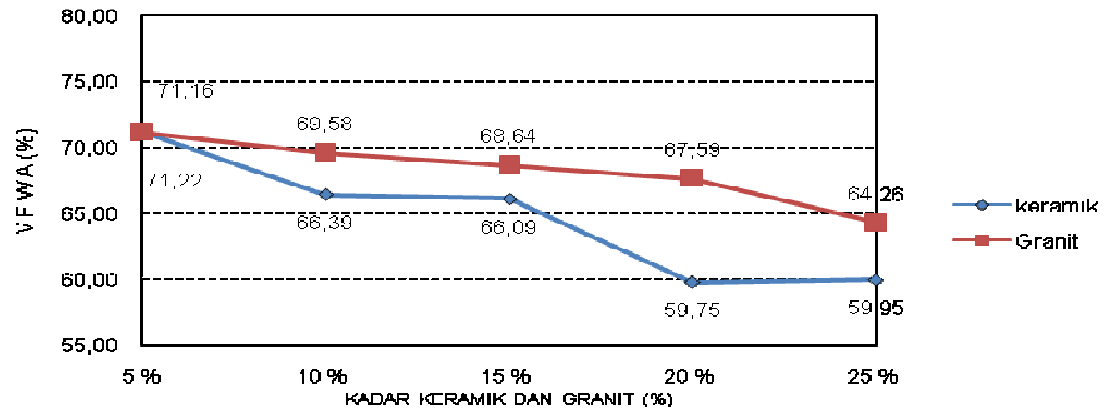

Gambar 4 Grafik hubungan variasi Filler terhadap nilai VFMA

Dari gambar diatas terlihat bahwa nilai VFWA pada campuran aspal mengalami penurunan pada kadar 5\% dan akan terus menurun. Maka dapat diambil kesimpulan bahwa nilai VFWA mengalami penurunan seiring dengan bertambahnya kadar Filler Keramik dan Filler Granit dalam campuran AC-WC akan tetapi dari kedua filler ini nilai tertinggi terjadi pada filler granit dibandingkan nilai pada filler keramik. 


\subsubsection{Pengaruh Filler Keramik dan Filler Granit terhadap Stabilitas}

Hubungan antara kadar Filler Keramik dan Filler Granit dengan nilai Stabilitas dapat di lihat pada gambar 5 berikut :

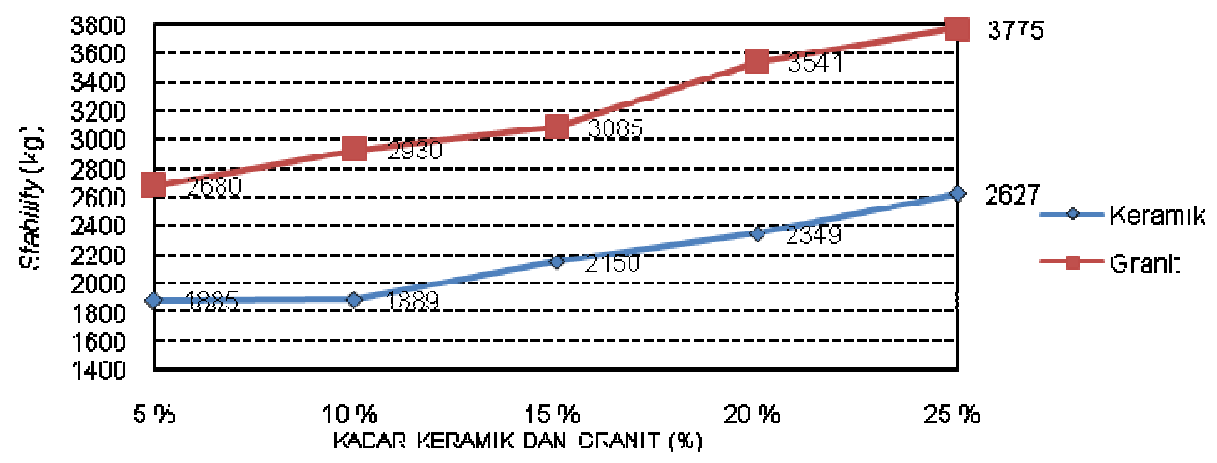

Gambar 5 Grafik hubungan variasi Filler terhadap nilai Stabilitas

Dari gambar diatas terlihat bahwa nilai Stabilitas pada campuran aspal mengalami peningkatan pada kadar 5\% dan akan terus mengalami kenaikan seiring dengan bertambahnya kadar filler sampai dengar Kadar 25\% baik untuk filler Keramik maupun Filler Granit. Hasil yang diperoleh menunjukkan bahwa nilai Stabilitas yang dihasilkan memenuhi persyaratan spesifikasi, dari Kedua Filler tersebut menunjukkan nilai Stabilitas untuk filler Granit lebih tinggi yaitu $3775 \mathrm{~kg}$ pada kadar 25\% dibandingkan filler Keramik yaitu sebesar $2627 \mathrm{~kg}$ kadar $25 \%$.

\subsubsection{Pengaruh Filler Keramik dan Filler Granit tehadap kelelehan (flow)}

Nilai kelelehan (flow) yang diperoleh dari hasil penelitian ini dapat dilihat pada gambar 6 dibawah ini.

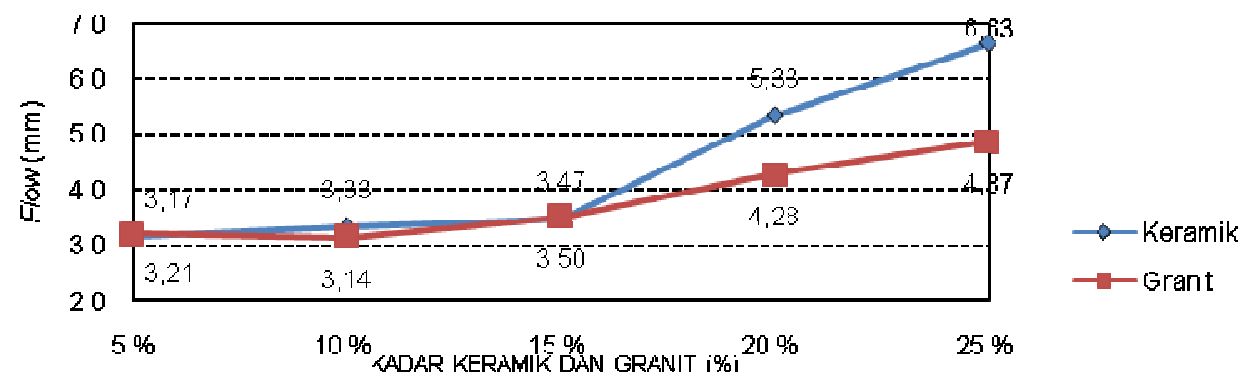

Gambar 6 Grafik hubungan variasi Filler terhadap nilai Flow

Peningkatan pada kadar 5\% dan yang paling tinggi terjadi kenaikan pada variasi Filler keramik. Maka dapat diambil kesimpulan bahwa nilai Flow mengalami peningkatan seiring dengan bertambahnya kadar Filler dan dari kedua jenis filler menunjukkan bahwa filler keramik lebih tinggi nilainya yaitu sebesar 6,63 mm pada kadar 25\% dibandingkan filler Granit yaitu sebesar 4,87 mm pada kadar $25 \%$. Hasil yang diperoleh menunjukkan bahwa nilai Flow yang dihasilkan memenuhi persyaratan spesifikasi. 


\subsubsection{Pengaruh Filler Keramik dan Filler Granit terhadap MQ (marshall Quotient)}

Nilai MQ yang diperoleh dari hasil penelitian ini dapat dilihat pada gambar 7 dibawah ini.

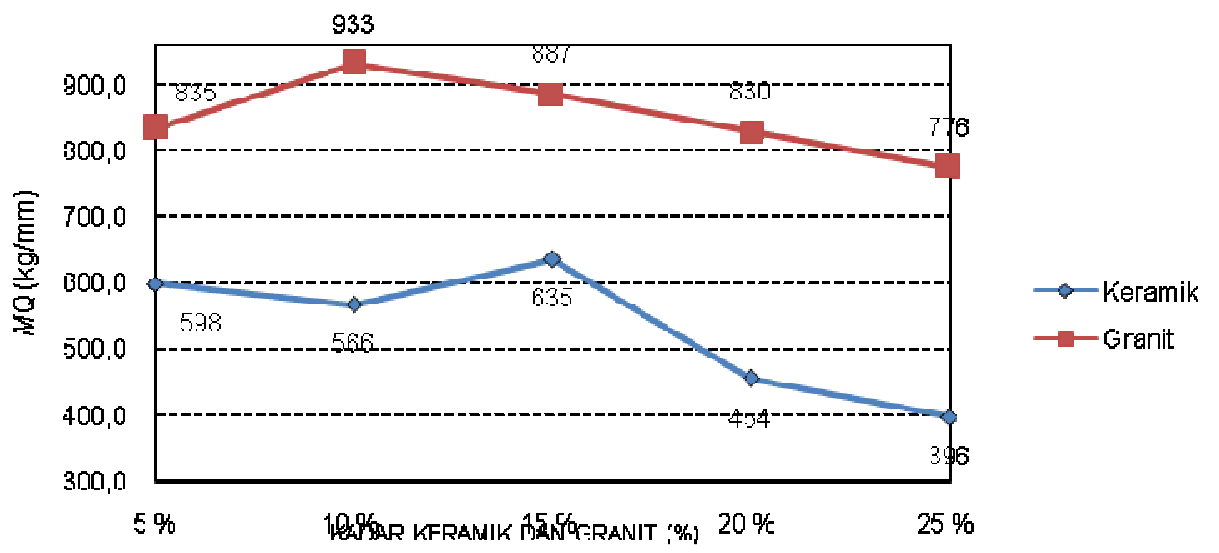

Gambar 7 Grafik hubungan Filler terhadap nilai MQ

Dari gambar diatas terlihat bahwa nilai MQ pada kadar $15 \% \mathrm{~K}$ tinggi yaitu sebesar $635 \mathrm{~kg} / \mathrm{mm}$ dibandingkan dengan kadar $5 \% \mathrm{~K}$ sebesar $598 \mathrm{~kg} / \mathrm{mm}$ dan mengalami penurunan pada $20 \% \mathrm{~K}$ sebesar $454 \mathrm{~kg} / \mathrm{mm}$ dan menjadi $396 \mathrm{~kg} / \mathrm{mm}$ pada kadar $25 \%$. Maka dapat diambil kesimpulan bahwa nilai MQ tinggi pada kadar $15 \%$ K. Sedangkan nilai MQ pada Variasi Granit terjadi kenaikan pada 10 $\% \mathrm{G}$ dan mengalami penurunan pada $25 \%$ G yaitu $776 \mathrm{~kg} / \mathrm{mm}$, akan tetapi secara umum hasil yang diperoleh menunjukkan bahwa nilai MQ yang diperoleh memenuni spesifikasi minimum $250 \mathrm{~kg} / \mathrm{mm}$ dan dari kedua jenis filler ini nilai tertinggi terjadi pada filler granit dibandingkan filler keramik.

Perbandingan antara nilai stabilitas dan flow, yang dipakai sebagai pendekatan terhadap tingkat kekakuan campuran. Bila campuran Aspal agregat mempunyai kelelehan rendah dan stabilitas tinggi menunjukkan sifat kaku,sebaliknya bila nilai kelelehan tinggi dan stabilitas rendah maka campuran cenderung plastis.

\subsection{Kesimpulan}

Dari hasil penelitian dan pembahasan maka dapat diambil kesimpulan sebagai berikut:

1. Komposisi penggunaan agregat pada campuran AC-WC (Asphalt ConcreteWearing Course) adalah 60\% agregat kasar, 34\% agregat halus dan 6\% abu batu.

2. Nilai kadar aspal optimum (KAO) yang diperoleh pada campuranAC-WC (Asphalt Concrete-Wearing Course) adalah 5,5\% dengan variasi Filler Granit dan Filler Keramik sebagai pengganti Abu Batu berkisar antara 5\% sampai $25 \%$.

3. Dari hasil pengujian parameter Marshall menunjukkan bahwa semakin bertambah persentase Filler Keramik dan Filler Granit dalam campuran AC WC maka tingkat kerapatan campuran(Density) akan terjadi penurunan dan VFMA semakin meningkat. 
4. Untuk nilai VMA mengalami peningkatan seiring dengan bertambahnya persentase filler granit dan filler keramik. Nilai yang didapat memenuhi spesifikasi Bina Marga 2010 yaitu Minimal $15 \%$ pada varian 0\% sampai dengan $25 \%$ baik keramik dan granit..

5. Nilai VITM yang telah memenuhi spesifikasi yang telah ditetapkan Bina Marga 2010 adalah pada $5 \%$ yaitu 5,46\% utuk keramik, 5\% yaitu 4,96\% dan $10 \%$ yaitu $5,32 \%$ untuk granit sedangkan Varian yang lainnya tidak memenuhi spesifikasi sedangkan batasan min 3,5 dan maks 5,5.

6. Untuk nilai Stabilitas, Flow dan MQ secara keseluruhan juga telah memenuhi spesifikasi Bina Marga 2010 dan dari Kedua Jenis Filler tersebut yang tertinggi terjadi pada Filler Granit.

7. Hasil dari penelitian ini adalah nilai parameter marshall yang telah memenuhi spesifikasi Bina Marga 2010 untuk Keramik terdapat pada varian 5\% K dengan nilai Density sebesar $2,322 \%$, VMA sebesar $17,15 \%$, VITM sebesar 4,94\%, VFWA sebesar 71,22\%, Stabilitas sebesar $1885 \mathrm{~kg}$, Flow sebesar 3,17 mm dan MQ sebesar $598 \mathrm{~kg} / \mathrm{mm}$ sedangkan Granit terdapat pada varian $5 \%$ $\mathrm{G}$ dan $10 \% \mathrm{G}$ dengan nilai Density sebesar $2,322 \%$, VMA sebesar $17,17 \%$, VITM sebesar 4,96\%, VFWA sebesar 71,16\%, Stabilitas sebesar $2680 \mathrm{~kg}$, Flow sebesar 3,21 mm dan MQ sebesar $838 \mathrm{~kg} / \mathrm{mm}$.

8. Untuk Keramik varian $10 \%, 15 \%, 20 \%$ dan $25 \%$ tidak memenuhi spesifikasi Bina Marga 2010 sedangkan untuk Granit varian 15\%,20\% dan 25\% tidak memenuhi spesifikasi Bina Marga 2010, nilai yang tidak memenuhi pada varian ini adalah nilai VITM.

\section{Daftar Kepustakaan}

1. Anonim, 1993, The Asphalt Institute, Mix Design For Asphalt Concrete and Other Hot-Mix Types, Manual Series (MS-2) 6th Edition, Lexington, Kentucky, U.S.A.

2. Anonim, 2006, Divisi 6 Perkerasan Beraspal, Departemen Pekerjaan Umum Spesifikasi Umum, Jakarta.

3. Anonim, 2010, Divisi 6 Perkerasan Beraspal, Departemen Pekerjaan Umum Spesifikasi Umum, Jakarta.

4. Sukirman, S., 1999, Perkerasan lentur Jalan Raya, Nova, Bandung.

5. Sukirman, S., 2003, Beton Aspal Campuran Panas, Granit, Jakarta.

6. Suprapto TM, 2004, Bahan dan Struktur Jalan Raya, Biro Penerbit Teknik Sipil Universitas Gajah Mada, Yogyakarta. 